\title{
Growing old in New Towns: a call for research on health and ageing in planned urban environments
}

\begin{abstract}
This paper focuses on the planning of New Towns in the UK in order to explore what the design and planning of urban spaces can tell us about which populations and their health matter and are prioritized, at different points in time. We concentrate on how ageing was conceptualized, and what this tells us about how ageing societies and bodies are accounted for and understood. Through the dynamic evolution of people and place, we can also come to see that what was once viewed as health promoting can become entangled with the causes of ill health. We recommend further multidisciplinary research into the planning of future cities and urban environments.
\end{abstract}

Key words: ageing; planning; urban health. 


\section{Growing old in New Towns: a call for research on health and ageing in planned urban environments}

\section{Introduction}

With the majority of global populations increasingly living in cities, urban environments will be the places to determine health and wellbeing (Institute 2016). Due to population ageing and 're-urbanisation' in Europe and Britain, post-retirement populations have increasingly become more urban, engaging with urban activities and the peripheral spaces surrounding cities (Allen 2007), and by extension also 'greying' suburbia (Siedentop, Zakrzewski et al. 2018). Calls to make urban environments 'age friendly' as well as 'healthy' are now commonplace. In this paper we call for critical research on how ageing and health is accounted for in the planning and design of urban environments. In order to explore the possibilities for this research agenda on ageing, health and (urban) planning, we draw attention to the planning and design of 'new' environments, using New Towns in the UK as a case study.

New Towns in the UK are 'new' urban environments created in the post-war era whose design and ideologies have since been replicated and proved influential around the world (Clapson, 2016). New Towns, built with a specific purpose, have a changing health profile as their residents age; whilst once they were planned spaces intended to alleviate the problems of older environments and health, they now present their own health-related problems to their rapidly ageing populations. New Towns are therefore a useful laboratory to look at the dynamic relationships between people and places.

We recommend further research into the planning of 'new' places and critical engagement with how the urban environment, health and ageing are defined and prioritized over time. Through the dynamic evolution of people and place, we can also come to see that what was once viewed as health promoting can become entangled with the causes of ill health. With the planning of 'Healthy New Towns' announced in 2016 by NHS England and Public Health England and currently ongoing, this call for research is timely. We argue that this agenda should take a multidisciplinary 
approach, with a particular focus on the long view, in order to examine the changing nature of ageing and its intersections with understandings of health and planning.

Ageing in place

In England, the majority of the population live in urban areas $(83 \%)$, and on average just over $16 \%$ of the urban population is over 65 years of age, although this varies significantly from place to place (Environment 2016). An ageing population with a wide range of health needs changes the requirements of urban space. There is growing recognition that the demands of ageing populations not only span health and social care resources, but also encompass the design and functioning of the places in which they live. The attention to these environments is multifaceted: from transport to street furniture, housing to public toilets, and community centres to policing (Biggs and Tinker 2007, Holley-Moore and Crighton 2015, OECD 2015, Tinker and Ginn 2015). As well as research into a variety of urban requirements for ageing populations, interdisciplinary work has focused upon the connections between health, ageing and material and social neighbourhoods (Peace, Kellaher et al. 2005, Peace, Holland et al. 2005, Gardner 2011, Milton, Pliakas et al. 2015), the design of buildings such as hospitals and care homes (Street and Coleman 2012, Buse, Nettleton et al. 2016), regeneration and housing interventions (Biggs et al 2000) and critiquing 'age-friendly city' social policies (Buffel et al, 2012). Whilst there is a long history of concern towards the links between urban planning, design and human health (Sheard and Power 2000; Hamlin 2010), sociologists have recently called for more critical engagement with the design and architecture of places and spaces (Martin, Nettleton et al. 2015), in order to explore how concepts and priorities surrounding health are 'built into' the environment. The design and planning of cities and urban spaces can tell us much about how the health of populations and societies are understood, which populations matter and are prioritized, at different points in time.

\section{The UK New Towns}

In order to explore possibilities for research about health, ageing and planned environments, this paper focuses on the planning of New Towns in the UK. Different waves of New Town construction were built (and are still built) with particular 
visions of health, the economy and their populations. New Towns were planned urban environments built following the 1946 New Towns Act, intially intended to move people out of overcrowded and bomb damaged cities (especially London). Over time their design and purpose altered (Alexander 2009; Hardy 1991). Whilst New Towns were designed and understood as 'healthy' spaces, with population ageing and change, accompanied by the ageing of these planned environments, they now have specific health problems as well as advantages. New Towns have one of the greatest expected increases in the proportion of the population aged over 65 (including many residents who moved to the towns when they were 'new').

The large-scale, planned new communities of the $20^{\text {th }}$ century - and indeed planned new communities around the world - all to some extent take their inspiration from the British Garden City movement in the $19^{\text {th }}$ century. The Garden City movement was a form of modernist urban planning, which aimed to create a 'better society', among the perceived disorder of the fast growing industrial cities and large scale rural to urban migration in the 19th century (Hobson 1999). Ebenezer Howard, credited with being behind the Garden City Movement in Britain, believed that de-centralising people and industries from overcrowded cities was the most effective solution to social problems (Hall and Ward 1998). Planning new urban spaces became a tool with which liberal social reformers could attempt to to diffuse social benefits across all social groups, as part of a reform movement to reduce class-based inequalities, such as over-crowding, symptomatic of unplanned industrial cities (Hobson 1999).

Combining the 'best from the city and the best from the country', a third space was conceptualised for the Garden Cities, aiming to put together natural beauty with parks and open spaces, roads and paths for easy access, full employment, high wages and low rents (Clapson 2016). Through looking at these plans and the ideologies behind them we can see that health was conceptualized as societal, with an aim to reduce inequalities through the provision of a different kind of environment. Garden Cities were designed for 'healthy living' - with planning space and planning health (as it was understood then) intertwined; it is notable that Raymond Unwin, one of the architectural planners of Letchworth Garden City later became Chief Architect at the Ministry of Health. 
Making material plans for the cities was also a way to bring the desirable behaviours associated with healthy living at the time into being. It was assumed through planning the space that the population would be engaged in a wide range of associations, clubs and societies - with a focus on 'rational recreation rather than the vices of drink and other irrational forms of leisure that wreaked havoc in cities' (Clapson 2016: 49). The absence of ageing as a health issue, or population of concern, in these plans is notable, but understandable given the relative lack of priority accorded to older people as a population group at the time. This situation, however, changed in the last decades of the twentieth century as lifespans increased and the needs of an ageing population became more apparent (Thane 2000; Greenhalgh 2018). We argue that examining the changing focus of planning new environments throws new light on when and why ageing became a public health imperative.

Within the planning of postwar reconstruction, New Towns, like the Garden Cities, were visions for a new, or renewed, society, population and even nation. Growing from the need to provide housing and employment, the Labour government at the time thought it could provide 'unity through housing' (Institute, 2018). New Town planning has been described as 'a quest for an ordered and rational urban form' and like the Garden City plans proposed to offer 'universal solutions to the problems and perceived chaos of the industrial city' (Hobson 1999). Many, such as Milton Keynes, were at the time specifically marketed to prospective residents as 'healthy' places to live - as opposed to the over-crowding, chaotic conditions in the larger city.

There have been different waves of 'New Town' construction in the UK; the largest and most well known being the New Towns that were planned and constructed across the UK after World War Two, to house overspill from London and other major urban areas. In the 1944 Greater London Plan, the out-migration of over a million people from London on these planned schemes was advocated (Hobson 1999) and in the fifty years after 1946, 28 New Towns were built in two concentrated bursts of activity (Hall and Ward 1998). Emerging at around the same time as the NHS, the creation of New Towns has been described as one of the most important social enterprises of the time (Chave 1966). 
The population that moved to the postwar New Towns consisted mostly of young families (Planning 1947). To take Harlow New Town for an example, which has been described as a 'pram town', almost $40 \%$ of the population consisted of children under 15, nearly double the national figure; the average age in Harlow in 1958 was 27, about ten years younger than the national average (Clapson, 1998). Again there was an emphasis upon close at hand employment and opportunities for social and recreational facilities in order for people to meet and contribute towards the life of the town. Similar to the Garden Cities, health was envisaged as relational and societal, as a product of a balanced and united community. Rather than a specific focus on the urban poor like the preceding plans for Garden Cities, the population of interest for New Towns was young families. We argue that further research is needed in order to examine how these spatial plans for young families have aged, and how they cater for - or not- their now ageing populations. Have New Towns aged well? Do they continue to cater for their original residents, or have they stayed best suited to younger people?

\section{Planning Healthy New Towns today}

Attempts to think about, and plan, the links between urban environments and health have been reiterated in different forms over time. The 'Healthy New Towns' programme, announced in 2016 with construction beginning in 2018, has its origins in the 2008 Healthy Towns project in England, which in turn has its precursors in the 'healthy cities' movement which has been circulating globally in planning circles since the late 1980s. As opposed to the upstream determinants of health as laid out in the planning of Garden Cities and the postwar New Towns, the focus of the Healthy New Towns of 2018, and Healthy Towns of 2008, is rather on specific conditions, such as obesity and dementia (see NHS England 2015; 2016; 2018).

Whereas the Garden Cities and postwar New Towns concentrated on improving the lives of working class populations, i.e. the overcrowded and disadvantaged workers in cities, the plans for the contemporary Healthy New Towns are much more focused on shaping exposure to and uptake of the risk factors for chronic disease, mirroring the increasing individualisation of public health problems. As well as the locus of health moving from the society or community to the individual, the role of the environment 
and the purpose to which it was being put is also different. In New Towns an improved environment was conceived of as a collective social good, whereas in the plans for Healthy New Towns the environment is used to 'design in' individual 'good' and healthy behavior (see Design Council, 2017)- and the political economy of risk no longer addressed.

Importantly, in comparison to the post-war New Towns, in the plans for Healthy New Towns the needs of ageing populations are dominant. A large part of how Healthy New Towns plan to improve health among their ageing populations is through the use of digital technologies, for example the use of electronic surveillance of older people and providing easier access to GP services through 'remotely logging into the surgery from the comfort of your living room' (Fry 2015). As health and its maintenance is individualized, perhaps some of the benefits of a societal approach to health - such as community spaces to keep active and socialize - are lost. Despite a focus on ageing in these plans and despite some community-based iniatives, the focus on the individual rather than community, and health-seeking behavior for older people being located inside the home rather than outside in the community, may add to the epidemic of loneliness which has been shown to lead to ill health (Green et al 2014; Green et al 2017).

As the health needs of the population change, these need to be encoded within the planning of urban environments. A clear example of this can be found in the changing, back and forth relationship with the car and mobilities. The Garden Cities were planned for walking, the New Towns planned much more consciously for the car and now, in a full circle, Healthy New Towns now encourage walking and physical activity and a move away from the car. In the sets of plans over time then we see a changing mobility and changing understanding of movement and health. What can be planned for health can later lead to ill health, depending on how health is defined and how the definition intertwines with the understanding of different populations.

Healthy New Towns are quite different to the New Towns and Garden Cities that came before them, however looking at the plans demonstrates the evolution over time of ideas surrounding what defines healthy spaces. Health, planning and ageing have 
been manifest in numerous ways as societal and political attention has shifted. The question of ageing as a planning concern is recent, as awareness of the unsuitability of urban (and rural) environments has grown (see Buffel and Phillipson, 2016) and older people have become a powerful lobbying group. There is still much to learn about the ways in which ageing challenges previously-held conceptualisations about health, place and planning. Some of the same issues remain (i.e. active travel, green space), but others are very specific (i.e. accessibility modifications), and these require a new research agenda

\section{Conclusions}

Combined with one of the greatest expected increases in the proportion of the population aged over 65 (including many residents who moved to the towns when they were 'new'), New Towns have some valuable lessons to offer us. The masterplans of the Garden Cities and New Towns were, in effect, blank canvases in which the ideal urban society could be imagined. Many New Towns were built with the needs and aspirations of working-age families and their children for safety, security, amenity and escape from the irritations of life in the city. Through the urban and spatial planning of New Towns, their creators also invoked ideas about what quality of life for its residents might mean and how exactly this might be realised. Concern with transporation to places of employment, the provision of retail opportunities, community amenities, green space and mechanisms to ensure that residents were not tempted by the 'vices' of alcohol were some of the many that animated New Town planners.

And yet these plans were not always successful and, like most instances of urban planning, rarely realized in the same ways that their master planners envisaged. As we have explored, this was rendered even more so as New Town residents grew older in an environment designed for their younger selves. The ways in which New Towns have (or have failed to) adapt to demographic shifts has thus become a twin concern of public health and urban planning in the UK, with international resonance for planned communities in many other countries. The new wave of Healthy New Towns do not share their predecessors' concern with public health as a social problem, and 
have tended to mirror the individualized framing of health that has prevailed since the late 1970s. However, they do recogonise the need to plan for the needs of older populations. They thus demonstrate important continuities and discontinuities with what came before. Healthy Towns may be being spun as a revolutionary urban form, but here we urge caution in interpreting them as such. There is much to be learned from previous experiments with health and planning: how they succeeded, why they failed and for whom. The history of New Towns may yet teach us new things.

\section{Recommendations for further research}

- There is a need for more research on New Towns and their changing demographics; how they have changed and how may change in the future.

- Research could address whether the health needs of older people are considered in plans for New Towns, and how these plans, and the needs they are responding to, changed over time.

- Lessons could then be learnt for adapting services and environments for a changing population - there is a need for flexibility in the design of urban environments to adapt to the changing age profiles of a population.

- These questions could be addressed with multi-disciplinary perspectives on ageing and urban environments.

- This research would contribute towards urban health agendas, histories of urban health, contemporary policy debates and debates on ageing and health.

\section{Acknowledgements}

[removed for peer review] 


\section{References}

Alexander, Anthony. 2009. Britain's New Towns: Garden Cities to Sustainable Communities. 1 edition. London; New York: Routledge.

Allen, C. (2007). "Of Urban Entrepreneurs or 24-Hour Party People? City-Centre Living in Manchester, England." Environment and Planning A: Economy and Space 39(3): 666-683.

Biggs, S. and A. Tinker (2007). What Makes a City Age Friendly? . London, Help the Aged.

Buse, C., et al. (2016). "Imagined bodies: architects and their constructions of later life." Ageing and Society 37(7): 1435-1457.

Chave, S. P. W. (1966). "Mental health in Harlow new town." Journal of Psychosomatic Research 10(1): 38-44.

Clapson, M. (2016). "Garden Cities and the English new towns: foundations for new community planning." L'ADC L'architettura delle città. The Journal of the Scientific Society Ludovico Quaroni 8.

Clapson, M (1998). Invincible Green Suburbs, Brave New Towns: Social Change and Urban Dispersal in Postwar England. Manchester University Press:

Manchester.

Council, D. (2017). "What is a healthy new town?". from https://www.designcouncil.org.uk/news-opinion/what-healthy-new-town.

England, NHS. (2015). "NHS launches new offer to put health at the heart of new communities." from https://www.england.nhs.uk/2015/07/healthy-newtowns/.

England, NHS. (2016). "NHS Chief announces plan to support ten healthy new towns." from https://www.england.nhs.uk/2016/03/hlthy-new-towns/.

England, NHS. (2018). Healthy by Design: the Healthy New Towns Network Prospectus. NHS England.

Environment, D. f. R. A. a. t. (2016). "Rural Population 2014-15."

Fry, T. (2015). "Healthy New Towns - again!" British Journal of Obesity 1(3): 114-115.

Gardner, P. J. (2011). "Natural neighborhood networks - Important social networks in the lives of older adults aging in place." Lournal of Aging Studies 25(3): 263-271. 
Goodwin, D. M., et al. (2013). "The role and status of evidence and innovation in the healthy towns programme in England: a qualitative stakeholder interview study." LEpidemiol Community Health 67(1): 106-112.

Green, J., Jones, A. and H. Roberts (2014). "More than A to B: the role of free bus travel for the mobility and wellbeing of older citizens in London." Ageing \& Society 34, no. 3 (2014): 472-494.

Green, J., Buckner, S., Milton, S., Powell, K., Salway, S. and Moffatt, S., (2017). A model of how targeted and universal welfare entitlements impact on material, psycho-social and structural determinants of health in older adults. $\underline{\text { Social }}$ Science \& Medicine, 187, pp.20-28.

Hall, P. G. and C. Ward (1998). Sociable cities: the legacy of Ebenezer Howard, J. Wiley.

Hobson, J. (1999). New Towns, the Modernist Planning Project and Social Justice: The Cases of Milton Keynes, UK and 6th October, Egypt, Development Planning Unit, University College London.

Holley-Moore, G. and H. Crighton (2015). The Future of Transport in an Ageing Society London, Age UK.

Institute, R. T. P. "New towns come of age." Retrieved March, 2018, from http://www.rtpi.org.uk/knowledge/networks/rtpi-cih-planning-for-housingnetwork/new-towns-come-of-age/.

Institute, R. T. P. (2016). "RTPI welcomes plans for 'healthy new towns'."

Martin, D., et al. (2015). Architecture and health care: A place for sociology.

Milton, S., et al. (2015). "A qualitative geographical information systems approach to explore how older people over 70 years interact with and define their neighbourhood environment." Health Place 36: 127-133.

OECD (2015). Ageing in Cities: Policy Highlights, OECD.

Peace, S., et al. (2005). Environment and identity in later life, McGraw-Hill International.

Peace, S. M., et al. (2005). "„The Influence of Neighborhood and Community on Well-Being and Identity in Later Life: An English Perspective." Home and identity in late life: International perspectives: 297-315.

Planning, M. o. T. a. C. (1947). Willesden and the new towns. London: 126.

Sautkina, E., et al. (2014). "Lost in translation? Theory, policy and practice in systems-based environmental approaches to obesity prevention in the Healthy Towns programme in England." Health Place 29: 60-66. 
Siedentop, S., et al. (2018). "A childless urban renaissance? Age-selective patterns of population change in North American and German Metropolitan areas." Regional Studies, Regional Science 5(1): 1-20.

Street, A. and S. Coleman (2012). "Introduction: Real and Imagined Spaces." Space and Culture 15(1): 4-17.

Tinker, A. and J. Ginn (2015). An Age-Friendly City: How far has London Come? London, Kings College. 